\title{
The Allocation of Talent: Implications for Growth
}

\section{Citation}

Murphy, Kevin M., Andrei Shleifer, and Robert W. Vishny. 1991. "The Allocation of

Talent: Implications for Growth." The Quarterly Journal of Economics 106 (2) (May): 503. doi:10.2307/2937945.

\section{Published Version}

doi: $10.2307 / 2937945$

\section{Permanent link}

http://nrs.harvard.edu/urn-3:HUL.InstRepos:27692664

\section{Terms of Use}

This article was downloaded from Harvard University's DASH repository, and is made available under the terms and conditions applicable to Other Posted Material, as set forth at http:// nrs.harvard.edu/urn-3:HUL.InstRepos:dash.current.terms-of-use\#LAA

\section{Share Your Story}

The Harvard community has made this article openly available.

Please share how this access benefits you. Submit a story.

Accessibility 
NBER WORKING PAPERS SERIES

THE ALLOCATION OF TALENT: IMPLICATIONS FOR GROWTH

Kevin M. Murphy

Andrei Shleifer

Robert W. Vishny

Working Paper No. 3530

NATIONAL BUREAU OF ECONOMIC RESEARCH

1050 Massachusetts Avenue

Cambridge, MA 02138

December 1990

We are grateful to Robert Barro, William Baumol, Olivier Blanchard, Avinash Dixit, steve Kaplan, Anne Krueger, Paul Romer, Lawrence Summers, and Robert Waldmann for helpful comments. We also appreciate the support of the National science Foundation. This paper is part of NBER's research program in Growth. Any opinions expressed are those of the authors and not those of the National Bureau of Economic Research. 
NBER Working Paper \#3530

December 1990

THE ALIOCATION OF TALENT: IMPLICATIONS FOR GROWTH

\section{ABSTRACT}

A country's most talented people typically organize production by others, so they can spread their ability advantage over a larger scale. When they start firms, they innovate and foster growth, but when they become rent seekers, they only redistribute wealth and reduce growth. Occupational choice depends on returns to ability and to scale in each sector, on market size, and on compensation contracts. In most countries, rent seeking rewards talent more than entrepreneurship does, leading to stagnation. Our evidence shows that countries with a higher proportion of engineering college majors grow faster; whereas countries with a higher proportion of law concentrators grow slower.

Kevin M. Murphy Graduate School of Business University of Chicago 1101 east 58 th street Chicago, IL 60637
Andrei Shleifer Graduate School of of Business Columbia University Uris Hall, Room 604 New York, NY 10027

Robert W. Vishny Graduate School of Business University of Chicago 1101 East 58th Street Chicago, IL 60637 


\section{INTRODUCTION}

When they are free to do so, people choose occupations that offer them the highest returns on their abilities. The most able people then choose occupations that exhibit increasing returns to ability, since increasing returns allow "superstars" to earn extraordinary returns on their talent [Rosen, 1981]. In these occupations, being slightly more talented enables a person to win a tournament, to capture a prize, to become promoted, or otherwise to gain a lot by being slightly better than the next person. For example, since everyone wants to listen to the best singer, she can earn a lot more than a marginally inferior singer, especially with records and tapes. In occupations with increasing returns to ability, absolute advantage is the critical determinant of pay.

Some people have strong comparative advantage from natural talent for particular activities, such as singing, painting or basketball. These people can earn vastly more by practicing these occupations than any others. But other people do not have such great specialized abilities, but at the same time possess great intelligence, energy or other generally valuable traits. Such people can become one of the best in many occupations, unlike the best singer or basketball player. They can become entrepreneurs, government officials, lawyers, speculators, clerics, etc. All these occupations exhibit increasing returns to ability, in that having marginally greater talent leads to a significantly higher payoff. The most able people then choose occupations where returns to being a superstar are the highest. In this paper, we discuss what determines their choices, and then argue theoretically and empirically that the allocation of talent has significant effects on the growth rate of an economy. 
What determines the attractiveness of an occupation to talent? First, the size of the market is crucial: being a superstar in a large market pays more than being a superstar in a small market and so will draw general talent. A person of great general athletic ability, for example, would rather be the 10 th best tennis player than the first best volleyball player, since far fewer people would pay to watch him play volleyball. Second, attractive activities have weak diminishing returns to scale. A superstar would want to spread her ability advantage over as large a share of the market as possible, but is limited by constraints on her time, physical ability, and more generally the size of the firm she can run. A surgeon can operate, at most, 16 hours a day, unless of course she can teach others to use the procedure and reap a return on their time. In contrast, an inventor who can embody her idea in a product overcomes the constraints on her physical time, but is still limited by the size of the firm she can run. Because of stronger diminishing returns to scale, even the most successful doctors do not make as much money as successful entrepreneurs. The faster returns to scale in an activity diminish, the less attractive it is to a person of high ability.

Finally, the compensation contract--how much of the rents on their talent the superstars can capture--determines the sector's attractiveness to talent. For example, if returns to innovation are not protected by patents and cannot be captured by an entrepreneur, entrepreneurship becomes less attractive. When individual output is difficult to measure or is not sufficiently rewarded when measured, talented people are underpaid. Teamwork without attribution is unattractive to superstars, as is horizontal equity. The more of the rents on her talent a superstar can keep, the more likely she is to join a sector. 
In different countries and time periods, talented people chose occupations in which it was the most attractive to be a superstar. When markets in a country are large and when people can easily organize firms and keep their profits, many talented people become entrepreneurs. Examples of such countries might be Great Britain during the Industrial Revolution, the United States in the late nineteenth and early twentieth century, and some East Asian countries today. In many other countries, talented people do not become entrepreneurs, but join the government bureaucracy, army, organized religion, and other rent seeking [Tullock, 1967; Krueger, 1974] activities because these sectors offer the highest prizes. In Mandarin China, Medieval Europe, and many African countries in this century, government service, with the attendant ability to solicit bribes and dispose of tax revenue for the benefit of one's family and friends, was the principal career for the most able people in the society [Baumol, 1990]. In Latin America and parts of Africa today as well as in many other countries through history, the most talented people often joined the army as a way to access the resources from their own countries (as well as from foreign conquests). In eighteenth century France, the best and the brightest also became rent seekers. The great chemist Lavoisier's main occupation was tax collecting, and Talleyrand was a bishop with a large tax income despite his prodigious entrepreneurial skills shown when he escaped to the United States after the French revolution. These examples show that in fact talent is often general rather than occupation-specific, and therefore its allocation is governed not just by comparative advantage but also by returns to absolute advantage in different sectors.

Which activities the most talented people choose can have significant effects on the allocation of resources. When they become entrepreneurs, they improve the 
technology in the line of business they pursue, and as a result, productivity and income grow. In contrast, when they become rent seekers, most of their private returns come from redistribution of wealth from others and not from wealth creation. As a result, talented people do not improve technological opportunities, and the economy stagnates. Landes [1969] believes that the differential allocation of talent is one of the reasons why England had the Industrial Revolution in the eighteenth century but France did not. In more recent times, the allocation of talent to the rentseeking sectors might be the reason for stagnation in much of Africa and Latin America, for slow growth in the United States, and for success of newly industrializing countries where these sectors are smaller.

The allocation of talent to rent seeking is damaging for several reasons. First, as the rent-seeking sectors expand, they absorb labor and other resources and so reduce income. The enormous size of government bureaucracies in some LDCs illustrates this effect. Second, the tax imposed by the rent-seeking sector on the productive sector reduces incentives to produce, and therefore also reduces income. A striking example of this is the difficulty of starting a firm in today's Peru described in De Soto's [1989] The Other Path. Finally, if the most talented people become rent seekers, the ability of entrepreneurs is lower, and therefore the rate of technological progress and of growth is likely to be lower. The flow of some of the most talented people in the United States today into law and financial services might then be one of the sources of our low productivity growth. When rent-seeking sectors offer the most able people higher returns than productive sectors, income and growth can be much lower than possible.

The sharp distinction we draw between productive and rent-seeking activities is 
exaggerated. Pure entrepreneurial activities raise current income because resources are used more efficiently, contribute to growth because technology is improved, and take profits away from competitors. Or take the case of traders in financial markets. Trading probably raises efficiency since it brings security prices closer to their fundamental values. It might even indirectly contribute to growth if more efficient financial markets reduce the cost of capital. But the main gains from trading come from the transfer of wealth to the smart traders from the less astute who trade with them out of institutional needs or outright stupidity. Even though efficiency improves, transfers are the main source of returns in trading. The same is true for some kinds of law, such as divorce and contract law, the army and the police in some countries, and to some extent organized religion. Although few activities are pure rent seeking or pure efficiency-improving, the general point remains: talent goes into activities with the highest private returns, which need not have the highest social returns.

Olson [1982] also addresses the relationship between rent seeking and growth. His idea is that "cumulative distortions" due to rent seeking reduce growth. Olson does not deal with the allocation of talent. Magee, Brock and Young [1989] discuss rent seeking in great detail and present a model of the allocation of labor between rent seeking and production. Like us, they present some evidence that lawyers have a detrimental effect on growth, using different data. They do not focus on the allocation of talent. Baumol [1990] makes the same basic point as we do that entrepreneurship can be "productive" or "unproductive," and the allocation of people between the two activities depends on the relative returns and provides many interesting historical examples. The ideas of our paper were developed independently. In particular, Baumol does not discuss the role of increasing returns 
to ability in explaining why rent seeking and productive entrepreneurship are in tact competing for the very same people, who are the most able in the society.

Section I of the paper presents a one-sector model of entrepreneurship and growth and discusses the increasing returns to ability that draw the most able people into entrepreneurship. We abstract from alternative uses of high ability to stress the importance for growth of allocating talent into the entrepreneurial activities.

Section II then considers the allocation of talent between two sectors with increasing returns to ability. It also explains why talented people may be drawn into sectors which experience an improvement in technology. or an increase in demand, making growth in these sectors self-sustaining. Section III introduces pure rent seeking as an alternative activity with increasing returns to ability, and shows when the most able people switch to rent seeking. We also discuss the implications of rent seeking for growth. Section IV presents some evidence on the effect of lawyers and engineers on growth. Section V concludes.

\section{Entrepreneurship and Growth: A One-Sector Model}

This section presents a model of entrepreneurship and growth. The model is based on Lucas [1978] and has been previously used by Kuhn [1988]. In the model, high ability people become entrepreneurs and hire low ability people in their firms. When they do, they improve the current productive techniques. As the improvement of the technique is imitated, everyone's productivity rises and income grows. In the model we set up, the rate of technological progress and of income growth is determined by the ability of the most able person engaged in entrepreneurship. The model thus illustrates the importance for growth of allocating the most able people to 
the productive sector of the economy.

We assume that there is a distribution of abilities in the population, with the support of $[1, a]$ and the density function $f(A)$. We measure a person's ability by how much he can improve the technology he operates. Ability in our model is unidimensional: we do not address the allocation of people to jobs because of particular aptitude in those jobs. Each person is alive for one period and the distribution of abilities is the same each period.

We assume that there is only one good in the economy, which is produced by many firms. Each firm is organized by an entrepreneur. If a firm is organized by an entrepreneur with ability $A$, its profits are given by

(1) $y=s \cdot A \cdot F(H) \cdot w \cdot H$,

where $s$ is the common state of technology, $F$ is the constant over time production function, $\mathrm{H}$ is the aggregate human capital (ability) of all the workers employed by this entrepreneur, $w$ is the workers' wage, and the price of the good is normalized to be 1 . We can think of $s \cdot A$ as the productivity parameter of the firm, where $s$ is the public level of technology and $A$ is the entrepreneur's contribution. The entrepreneur takes the current state of technology $s$ and the wage $w$ as given. $F$ is a standard concave production function.

The profit function (1) builds in our key assumptions. The more able entrepreneurs can earn more than proportionately to their ability higher profits from operating the same technology as the less able entrepreneurs. This is because their output and therefore revenues rise with their ability but their costs do not. There is, therefore, an increasing return to ability. This assumption makes it more attractive 
for the most able people to become entrepreneurs, for two reasons. First, they can earn more than proportionately higher profits for a fixed size of the firm $\mathrm{H}$. Second, the more able expand the size of the firm so that they can spread their ability advantage over a larger scale. The concavity of the production function $\mathrm{F}$ determines how strongly the returns diminish with scale, and so measures how much one can benefit from high ability.

The first-order condition with respect to $H$ is given by

(2) $s \cdot A \cdot F^{\prime}(H)=w$,

so the more able people, obviously, run larger firms. In the extreme case of constant returns to scale, the most able entrepreneur captures the whole market. In the case of diminishing returns, his ability to expand is limited but he still runs a larger firm.

Each person in the model lives for one period. He decides whether to become an entrepreneur or a worker. If he becomes an entrepreneur, he picks the size of his firm $H(A)$ according to (2), and then earns a profit as in (1). If he becomes a worker, he earns w A A We have the increasing return to ability in entrepreneurship since someone with double the ability earns double the income as a worker, but more than double the income as an entrepreneur for a fixed firm size. In fact, what matters here is that returns to ability in entrepreneurship relative to other work be increasing.

A person becomes an entrepreneur when

(3) $s \cdot A \cdot F(H(A)) \cdot w \cdot H(A)>w \cdot A$,

and a worker otherwise. The more able people become entrepreneurs in equilibrium. 
and the less able ones become workers. There is a cutoff ability $\mathrm{A}^{*}$ such that those with higher ability become entrepreneurs and those with lower ability become workers.

The demand for workers by entrepreneurs must equal the supply of workers

(4) $\int_{1}^{A^{*}} \operatorname{Af}(A) d A=\int_{A^{*}}^{a} H(A) f(A) d A$

Equation (4) describes how the real wage adjusts. If there are too many workers and too few entrepreneurs, there is excess supply of labor and so the best workers want to switch to entrepreneurship. Conversely, if there are too few workers, the wage is high and the marginal entrepreneurs would rather become workers.

To specify the growth model, we need to describe the evolution of technology s. We assume that the state of technology today is the state last period times the ability of the most able entrepreneur last period

(5) $s(t)=s(t-1) \cdot($ maximum ability of an entrepreneur at $t-1)$.

This assumption says that last period's best practice becomes common knowledge this period and is therefore accessible to any entrepreneur, who can then improve on it. The constantly improving technology generates permanent growth in our model. In addition, the assumption that the entrepreneur does not capture the future returns from his innovation builds in the standard externality, as in Arrow [1962]. As in Arrow, this assumption generates inefficiency in some versions of the model.

The model we presented does not distinguish between innovation and running firms. In fact, they are distinct activities and in principle can be done by different 
people. In this case, how the returns from innovation and managing are divided can influence the willingness of people to become innovators. This is one of the examples of how contracting can influence the allocation of talent. Historical experience, especially from the British Industrial Revolution, shows that the two functions (innovation and management) have very often been combined in the same person, suggesting that the problem of splitting the rewards is substantial enough to overcome the forces of comparative advantage.

This model is essentially static, since agents take the state of technology as given. The equilibrium is easy to describe. Each period, all agents with ability above A* become entrepreneurs, and those below $A^{*}$ become workers. The profit function and the income of workers are homogeneous in $s$ and $w$, which means that $A^{*}$ is constant over time. The same part of the distribution becomes entrepreneurs each period. Technology, wages, profits, and income per capita all grow at the constant rate a - 1 given by the ability of the best entrepreneur. This person determines the rate of growth of this economy.

The allocation of resources in this economy is first-best efficient. This means both that the growth rate is efficient, and that the cutoff ability level $\mathrm{A}^{*}$ between entrepreneurs and workers is efficient. The latter result obtains because both the social and the private product of the least able entrepreneur is exactly equal to his wage as a worker. The efficiency of the growth rate is very special: it is a consequence of having only one sector and not having any effort supply decisions by entrepreneurs that might be distorted. At the same time, the flavor of the result that more talented people are allocated to entrepreneurial activities with beneticial consequences for growth is going to be preserved in more general specifications. 
This simple model illustrates several general principles. First, the most able people in the society enter occupations where they can take advantage of increasing returns to ability. In this model, there is only one such activity-entrepreneurship-and so the question of which sector with increasing returns to ability to enter does not arise. When the most able people become entrepreneurs, they organize production and improve the available techniques. Second, the growth rate of the economy is determined by the ability of the entrepreneurs. It is therefore essential for growth that the most able people turn to entrepreneurship. Next, we examine the implications of introducing an alternative sector that competes for the talents of the entrepreneurs.

\section{A Two-Sector Model}

In this section we discuss the allocation of talent between sectors. The determinant of attractiveness of a sector that we model formally is the extent of diminishing returns to scale. Nonetheless, in interpreting the results, it is important to remember that market size and contracts also affect the allocation of talent.

Suppose that there are two sectors rather than one. Each sector has its own concave production function, but they are identical in all the other respects. Suppose also that preferences are Cobb-Douglas, so that the same fixed share of income is spent on a given good each period. Denote the share of income spent on good 1 by b. For this model, we can prove the following:

Proposition: If the production function for good 1 is more elastic than that for good 2 , then each period the most able people down to some constant over time threshold ability level $A_{1}$ become entrepreneurs in sector 1 , the next range of ability down to a 
constant over time $A_{2}$ become entrepreneurs in sector 2 , and the least able people become workers.

The most able people are all drawn into the sector with less diminishing returns (higher elasticity of output with respect to labor), because they run larger firms there and so can spread their ability advantage over a larger scale. The quasi rents accruing to talent are higher in that sector. Productivity in each sector grows at the rate given by the ability of the most able entrepreneur in that sector, which of course is higher in sector 1 . The real wage grows at the rate $g=a^{b} \cdot A_{1}^{1-b}$, which is the weighted average of productivity growth rates in the two sectors. At the same time, the price of good 1 falls over time relative to that of good 2, since technological progress is faster in sector 1 . The fall in the relative price of good 1 exactly offsets the increase in the relative productivity, so that in equilibrium revenues and profits in each sector grow at the same rate $g$ as do the wages. Because revenues, profits, and wages all grow at the rate $\mathrm{g}$, the cutoff ability levels $A_{1}$ and $A_{2}$ between sectors remain constant over time.

There is a stark inefficiency in this model. At the social optimum, the most able person becomes an entrepreneur in one sector, and the second most able person in the other sector. That way both sectors' productivity grows at the maximum possible rate. In equilibrium, however, the second most able person would rather be in the sector with less rapidly diminishing returns, since the first one captures only a small part of that sector and there is still more money for the second most able person to make in this than in the other sector. Each person is quasi-rent seeking, and quasi rents on ability are higher in sector 1 . As a result, all the most able people become entrepreneurs in sector 1, where the externality from all of them other than the most 
able is zero. In contrast, the person generating the externality in sector 2 is much less able, and as a result that sector's productivity grows at a much lower rate. The pursuit of quasi rents by the able people unbalances growth of the two sectors, with the result that one grows inefficiently slow.

This inefficiency is much more general than our model, in which only the most able person determines the rate of technological progress, would suggest. Obviously, the result that people of comparable ability bunch into the same sector does not depend on the form of externality. So unless such bunching generates the maximum externality, there will be an inefficiency. We see no reason why bunching of people of comparable ability into the same sector is optimal, so many types of externality generate an inefficiency. For example, if the externality depends on the average or total ability of entrepreneurs in a given sector, it may still be efficient to have very similar distributions of abilities in the two sectors. One can argue perhaps that there is an agglomeration economy of people with comparable abilities working in the same sector, and that the pace of innovation depends on that. In this case, one would want many innovators of comparable ability working together. But again, there is no reason to think that the number of people needed to take advantage of the agglomeration economy is as large as this model would put into the same sector, or that the agglomeration economy is the highest in the sector where the most talented people go. The equilibrium we have is inefficient, except by coincidence. Of course, the inefficiency is smaller when individuals have comparative advantage at working in particular sectors or when there are increasing returns to agglomeration of talent.

The most able people tend to flow into a sector where they can spread their ability advantage over the largest scale. In the model, this means that they run the 
largest firms in the economy, a prediction that seems patently false. We have assumed in this model that the compensation arrangements enable the most able people to collect full quasi rents from their talents (though none of the future rents because of perfect imitation). If this is not the case in some sectors, the most able people would move into sectors where they collect the most even if firms are smaller. The reason that people cannot collect full quasi rents have to do with imperfect contracting and problems of allocating output to individuals. The allocation is then determined by the compensation contract, and not just by technology.

In fact, differences in contracts between industries are probably as important or more important than physical diminishing returns to scale. In industries where it is easy to identify and reward talent, it might be possible to pay the able people the true quasi rents on their ability and so to attract them. This is probably true in industries at the early stages of their development, where able people can start and run firms rather than work as part of a team. Perhaps the reason the auto industry attracted enormous talent when it started but attracts much less talent now is that talent was easier to identify and reward then. Starting one's own company is obviously the most direct way to capitalize on one's talent without sharing the quasi rents. Talent will then flow into industries where it is easy to start a firm, which would be newer and less capital-intensive industries. Also, talent will flow into sectors with less joint production, so it is easier to assign credit and reward contributions. Finally, the most talented people will not go into activities where horizontal equity and other ethical considerations prevent them from capturing the quasi rents on their ability. Meritocracy is an obvious attractor of talent.

We emphasize that what matters for the allocation of talent is the relative 
rewards in different sectors. If all sectors tax quasi rents to ability equally, then obviously the compensation contract will not make any of them more attractive. This logic also suggests that there are two ways for a particular sector to be attractive to the high ability people. The first is for this sector to have attractive compensation contracts; the second is for the other sectors to have unattractive contracts. For example, the reason that more talented people might become inventors in Japanese manufacturing might not be that they are particularly well rewarded there, but rather that compensation in law or government is even less attractive. Altemative opportunities are thus a key determinant of the allocation of talent.

The Cobb-Douglas assumption on preferences gives the result that the allocation of talent across sectors is constant over time. If we relaxed this assumption, the allocation of talent would change over time and the analysis would become more complicated. The Cobb-Douglas assumption also has the unfortunate implication that the level of technology in a sector does not affect who goes into it. There is thus no sense in which the most talented people are attracted to "hot" sectors that experience a technology shock or a price rise (although of course the sector to which the best people go grows faster). To analyze how the allocation of talent might change in response to such shocks, in order to explain for example the U.S. experience in the 1970s and 1980s, we need to depart from the simple framework. Below we consider one plausible framework and look at the static allocation problem rather than a growth model.

Consider a one-period model with 2 sectors with prices $p_{1}$ and $p_{2}<p_{1}$ and identical production functions. In our current model this could not be an equilibrium since all entrepreneurs would rather be in sector 1 than in sector 2. But suppose that 
there are only a fixed number of firms $n_{1}$ in sector 1 and $n_{2}$ in sector 2 and there is no free entry. Then entrepreneurs bid for the opportunity to run the firms and the owners of these firms earn quasi rents on their fixed factor. The equilibrium is easy to describe. The most able $n_{1}$ people go into sector 1 , the next $n_{2}$ go into sector 2 , and the rest become workers. Let the ability of the least able entrepreneur in sector 1 be $A_{1}$ and that of the least able entrepreneur in sector 2 be $A_{2}$. The entrepreneur with ability $A_{2}$ earns $w \cdot A_{2}$, and the rest of his profits go to the fixed factor in sector 2. Similarly, the least able entrepreneur in sector 1 earns what the most able entrepreneur in sector 2 does, and the rest of his profits go to the fixed factor in sector 1 .

In this equilibrium, the more able people enter the hotter sector with the higher price, and free entry does not make them indifferent between sectors. The reason that the more able people end up in the hotter sector is that they bid more for the fixed factors because it is worth more to them to gain access to these factors. The fixed factors get the rents of the least able people gaining access to them, just as in Ricardo, and the more able people earn quasi rents on their ability as well.

We describe this extension for two reasons. First, it explains why the implausible feature of our basic model. namely that the level of technology does not affect the allocation of talent, is not really a problem. More importantly, this extension helps explain some episodes of why changes in particular sectors can attract a different type of talent into that sector. Suppose that there is a technological improvement in some sector, say financial services, and so the output per unit of ability in that sector rises sharply. Suppose also that demand is elastic, and that the number of firms in that sector is fixed in the short run. In this case, we might see that the ability of people 
moving into this sector rises, since they are able to profit the most working in a scarce number of firms. By doing so, they would pay the most to the owners of those firms for the privilege of working there. Without free entry, we would see that some of the benefits of the productivity increase would go to the firm owners, and some to the new employees who can produce the most.

When the ability of the most talented employees joining a sector rises, so does technological progress in that sector. This illustrates an important positive feedback in this model: when a sector with elastic demand experiences a positive technology shock, it attracts better talent and so technology improves further. Such continuation of the original innovation or other rent-creating shock through attraction of talent describes growth of many industries [Porter, 1990]. This model might explain, for example, the enormous technological progress in the U.S. financial services in the 1980 s, after deregulation.

\section{Rent Seeking and Growth}

In this section, we introduce rent seeking into the 1-sector growth model. We have described rent seeking in detail in the introduction; here we simply take it to be a tax on the profits of the productive sector. Specifically, we assume that when an entrepreneur earns a profit $y, T \cdot y$ is taken away by rent seekers through bribes, taxes, fees, and other costs of doing business in a rent-seeking society. We assume that $T$ is exogenous. One might argue in contrast that the amount of rent seeking is a function of the level of development, so that $T$ is a function of the level of income or the stability of government [Olson, 1982]. For simplicity, we assume that there is no productive component to rent seeking; it is therefore not a completely accurate 
description of financial services, law, or organized religion. We assume that rent seekers tax profits rather than all income, including wages, to simplify the analysis. This assumption leads to a distortion of allocation of people between entrepreneurship and work, but to no distortion in the size of the firm once a person becomes an entrepreneur. Of course, some taxes, such as the famous growth tax in India which imposes a penalty on revenue increases beyond a certain rate, distort the size of the firm as well [Little, Mazumdar, and Page, 1987].

The rent-seeking technology is also subject to increasing returns to ability and diminishing returns to scale. We assume that the rents collected by a person with ability $\mathbf{A}$ are given by

(6) $R=\frac{A \cdot G(H) \cdot T \cdot Y}{\int A G(H) f(A) d A}-w \cdot H$ rent seekers

where $H$ is the total human capital or ability of others that this rent seeker employs, $Y$ is the aggregate profits of the entrepreneurs, and $G(H)$ is the concave production function in the rent-seeking sector. In this specification, the share of total gross rents $T \cdot Y$ collected by the rent seeker of ability $A$ is proportional to $A \cdot G(H)$. Total gross rents collected by the rent seekers thus automatically add up to the total revenues lost by the entrepreneurs. We assume for simplicity that there is no technological progress in rent seeking. This assumption allows us to keep the model homogeneous in the state of technology s. The rent-seeking technology, like the productive technology, allows more able people to earn higher profits at a fixed size $\mathrm{H}$ as well as to expand $\mathrm{H}$ to maximize profits. In this respect, rent seeking is similar to entrepreneurship. 
Each person now has three choices: entrepreneurship, work, and rent seeking, and he picks the most attractive option. If it is one of the former two, he also sets the size of the firm. In equilibrium, the wage adjusts until the combined demand for workers by the productive and the rent-seeking sector is equal to the supply of workers

$$
\begin{aligned}
& \text { (7) } \int H(\mathbf{A}) \mathbf{f}(\mathbf{A}) \mathrm{dA}+\int H(\mathbf{A}) \mathbf{f}(\mathbf{A}) \mathrm{dA}=\int A f(\mathbf{A}) \mathrm{dA} \\
& \text { rent seekers entrepreneurs workers }
\end{aligned}
$$

We consider two cases. In the first, the production function (F) for output is more elastic with respect to $H$ than the production function $(G)$ for rent seeking; in the second it's the other way around. The results are similar to those of the twosector model. In the first case, the most able people go into the productive sector where firms are the largest, the next group goes into rent seeking, and the least able become workers. The cutoff ability levels are constant because the model is homogeneous in the level of technology s and so the allocation decision is the same each period. In this case, the level of technology s, productivity, wages, profits, and aggregate returns to rent seekers all grow at the rate a--the ability of the most able person in the economy. The growth rate is optimal since this person is an entrepreneur. However, the level of income is lower than it would be without rent seeking. First, some workers are allocated to the rent seeking rather than productive sector and as a result output is foregone. Put differently, demand for workers in the rent-seeking sector drives up wages and so reduces equilibrium employment in the productive sector. Second, the less able entrepreneurs become rent seekers, and so do not organize production. Although this does not lead to the reduction in the growth rate, it leads to a once-and-for-all reduction in the level of income. 
The situation is worse when the production function for rent seeking is more elastic and so the most able people become rent seekers since firms (correcting for compensation contracts) are the largest in that sector. The next group becomes entrepreneurs and the least able are workers. Now output grows at a lower rate than a, since the most able entrepreneur is no longer the most able person available. We now have three distortions from rent seeking. It absorbs labor, it distorts the choice of least able entrepreneurs who now become workers, and finally, it turns the most able people, who are pivotal for growth, into rent seekers. The model thus captures the crucial point that rent seeking can reduce growth (and not just the level of income) because it attracts potential innovators and entrepreneurs. As the ability of the most able person who becomes an entrepreneur falls, so does the growth rate.

This model makes several interesting predictions. First, suppose the tax rate $\mathrm{T}$ on entrepreneurial profits falls. This fall can correspond to the improvement in the property rights as suggested by North and Thomas [1973], but also to a reduction in corruption or in taxes. The first direct effect of this fall is to reduce the size of the rent-seeking sector. Workers move out of this sector and into production. Also, in the case where the most able people are entrepreneurs, the most able rent seekers move out and become entrepreneurs since incentives for this activity have improved. Although the growth rate in this case remains at a, the level of income jumps as resources move from rent seeking into entrepreneurship and production.

The case where the most able persons were rent seekers is different. As the tax rate $T$ falls, the least able rent seekers become entrepreneurs, and so the ability of the best entrepreneur rises. As a result, not only does the level of income jump, but the growth rate increases also as the person determining the growth rate of 
technology is now more talented. This result demonstrates perhaps the most important cost of a large rent-seeking sector (high $\mathrm{T}$ ). By drawing people out of entrepreneurship and into rent seeking, it reduces the growth rate of the economy permanently. The result also demonstrates how a one-time reduction in the extent of rent seeking can permanently raise the growth rate of the economy. Barro [1989] finds that countries with smaller government consumption relative to GDP grow faster, which is what our theory would predict if government consumption was a measure of the tax rate $T$.

In this model, changes in the tax rate $\mathrm{T}$ do not affect whether the most able person is an entrepreneur or a rent seeker. The reason is that the most able person has the strongest comparative advantage at being in the sector that he is in, and so is the last to switch. For example, as $\mathrm{T}$ rises, there is more entry into the rent-seeking sector but the entry is by people who have the least attachment to other sectors. This entry drives down the returns without affecting the allocation of inframarginal people. Where the most able person goes is determined in the model only by the relative elasticity of the two production functions, or how fast the diminishing returns set in the two activities. Since the career choice of the most able people determines the growth rate, how fast returns to scale diminish in entrepreneurship and in rent seeking is one of the key determinants of growth.

More generally, the allocation of talent between entrepreneurship and rent seeking is determined by market size and by the nature of contracts as well as by firm size (diminishing returns to scale) in the two types of activities. The puzzle that must be addressed is why, in most countries and times, talented individuals choose rentseeking activities, and the entrepreneurial choice is a fairly rare exception. Rent 
seeking seems to have an inherent advantage as a career choice. Table I summarizes some characteristics of countries and markets that influence the allocation of talent; in the following we try to discuss why the choice is so often rent seeking.

Rent-seeking activities are attractive when the potential amounts to be taken are large. When the "official" rent-seeking sectors such as the government, religion, or the army are big and powerful, the resources (and power) that a talented person gets by joining them and succeeding are large. As a result, these sectors attract talent. In such countries, the official institutions have well-defined property rights over private wealth. Because the "official" rent-seeking institutions are and have been extremely . powerful in most countries, this type of rent seeking often attracts talent.

Countries with poorly defined property rights also attract talent into rent seeking, since success at redefining these property rights brings high rewards. Rent seeking pays because a lot of wealth is up for grabs. In these cases, rent seeking is "unofficial" and takes the form of bribery, theft, or litigation. In the United States today, lobbying to influence the Congress and litigation are examples of this activity, which is so attractive because the redistributed wealth is enormous. In many countries, such "unofficial" rent seekers are official agents of the government, who use their official positions to collect unofficial rents. Customs officials in Equatorial Guinea take a cut of meat and liquor imports allegedly to "inspect" them. Like the "official" rent seeking, "unofficial" rent seeking outcompetes entrepreneurship for talent when wealth available for taking is larger.

Importantly, rent seeking unlike entrepreneurship usually deals with capital and other forms of wealth, which rent seekers fight over. Entrepreneurship typically allows the innovator to capture a portion of a market for some period of time, which 
is in most cases much less lucrative than getting one's hands on a piece of the country's wealth. Moreover, a country with large wealth but slow growth is especially attractive for rent seeking. The reason is that new goods often have more than unitary income elasticity of demand, and therefore future growth is essential for the profitability of innovation. Slow growth then reduces the attractiveness of innovation and entrepreneurship. This logic suggests that the productivity growth slowdown can be self-sustaining: as talent leaves entrepreneurship and growth slows, the returns to entrepreneurship fall further relative to those to rent seeking. We thus expect rent seeking to prosper in countries with substantial wealth and slow growth, such as the United States and Argentina today.

Feasible firm size, broadly interpreted, also often benefits rent seeking at the expenses of entrepreneurship. When rent seekers such as government officials or the military have substantial authority and discretion, they can expand their operations and collect larger sums unhindered by law or custom. In this respect, poorly defined property rights are responsible not just for large potential markets for rent seeking, but also for the ability of rent seekers to run larger "firms."

In entrepreneurship, physical diminishing returns to scale are only one limitation on firm size. In many less developed countries, legal restrictions on entry and on expansion, such as industrial capacity licensing, are a government-imposed limitation on firm size that makes entrepreneurship less attractive. Access to credit is also a crucial determinant of feasible firm size, and therefore of the attractiveness of entrepreneurship. Because rent seekers themselves often limit the ability of entrepreneurial firms to expand to maximize their own income, high returns to rent seeking often go with low returns to entrepreneurship. Entry and capacity 
restrictions, for example, invite bribes. In contrast, in countries where firms can easily organize and expand with few constraints from the state and from the capital markets, entrepreneurship will be attractive to the most talented relative to rent seeking. When rent seekers tax entrepreneurs by limiting firm expansion, the most able entrepreneurs suffer and the best potential entrepreneurs become rent seekers.

Perhaps the single most important determinant of the allocation of talent is the compensation contract. The ability of rent seekers to keep a large chunk of the rents on their talents, whether legally or illicitly, raises the attractiveness of rent seeking. In many countries, official positions come with a territory of being able to collect bribes. People pay hundreds of thousands of dollars for positions with the power to allocate supposedly free water to farmers in India, since these jobs give them monopoly rights to charge for water. Tax farmers throughout history bid fortunes for positions. Illegal rent seeking is the most attractive when it is protected by the state. What distinguishes these rent-seeking activities is that, at the margin, rent seekers can keep all or most of the return from their ability.

In market rather than official rent seeking, such as some forms of law and speculation, the output of rent seeking is often easily observable, and therefore can be rewarded. This might not be true in entrepreneurial jobs where the inventor cannot start his own firm but must work as part of a team in a large firm. In mature manufacturing industries in the United States, for example, it is extremely hard to identify individual contributions and to reward them accordingly even if they are identified. The difficulty of observing output might drive the potential entrepreneurs out of such industries and into rent seeking. The observability of output and the possibility of rewarding talent is probably the most important reason why so many 
talented people go into rent seeking in the United States today.

To summarize, talent in the rent-seeking sectors in many countries benefits from property rights that enable rent seekers to claim a substantial chunk of the productive output through official and unofficial expropriation. As talent joins the rent-seeking sectors, it expands and improves them. The higher taxes on productive activities reduce the returns to entrepreneurship, and drive even more talent into rent seeking. Large rent-seeking institutions and weak rent-protecting institutions draw talent out of entrepreneurship. One benefit of the shrinking rent-seeking institutions, such as the decline of central government, is that talent moves into productive activities. As the New York Times described Hungary's move to capitalism, "Government now has to compete with business for talented workers."

In some countries, entrepreneurs have managed to at least in part avoid the tax from rent seckers by becoming rent seekers themselves. In these countries, it is common for government officials to own businesses run either by themselves or by their relatives, and to protect these businesses from competition or from bribes by virtue of their government positions. Misallocation of talent nonetheless persists, since a large chunk of these people's time is spent in rent-seeking activities designed to foster their own businesses at the expense of those of the competitors.

Our model has one additional interesting implication. Suppose that the most lucrative sector for the most talented is rent seeking and that there is a dominant group in the population that has access to that sector. Suppose this group now excludes some ethnic or racial minority from access to the rent-seeking sector, such as the army or the government. In this case, the most able people from the excluded group must go into other sectors, one of which might very well be entrepreneurship. 
If the exclusion is effective, and if the overall distribution of abilities is the same for each group, this means that the ability of the most able entrepreneurs rises. The growth rate of the economy then also rises as a result of this exclusion. Moreover, exclusion of others benefits the dominant group, both because it leaves them a greater share of the rent-seeking pie, and because the size of that pie rises as the quality of entrepreneurship improves. Competition for the rent-seeking positions may in part explain why Jews have been excluded from many rent-seeking occupations in Europe, the Chinese in Malaysia, and the Indians and Lebanese in Africa. Faster growth can be one of the few inadvertent benefits of discrimination in rent seeking. Of course, discrimination against minorities in entrepreneurship hurts both them and the majority.

\section{Some Evidence}

A major implication of our paper is that the allocation of talented people to entrepreneurship is good for growth, and their allocation to rent seeking is bad for growth. Unfortunately, it is hard to directly measure the allocation of talent to these two types of activities. Barro [1989] provides some evidence that high government consumption and a high number of coups, which might both measure the extent of rent seeking, have a negative effect on growth, but this finding is too indirect. An alternative approach is to associate individual occupations with entrepreneurship and rent seeking. Magee, Brock, and Young [1989] have in fact found data on the number of lawyers in thirty-five countries, and found that countries with more lawyers grow slower. We have found data on the numbers of people in different occupations in different countries, but instead used data on college enrollments in different fields 
for a large cross-section of countries collected by UNESCO. We use the data on college enrollment in law as a measure of talent allocated to rent seeking, and on college enrollment in engineering as a measure of talent allocated to entrepreneurship. Although lawyers do different things in different countries, and undergraduate enrollments might not be a good proxy for the extent of each activity, these are the best measures of rent seeking and entrepreneurship we could find.

We use Barro's [1989] data set that augments the Summers and Heston [1988] data base. In fact, we frame our analysis as an extension of Barro's regressions. The variables we use for each country are the growth rate of real GDP per capita between 1970 and 1985, real GDP per capita in 1960, average from 1970 to 1985 of the ratio of real government consumption (exclusive of defense and education) to real GDP, primary school enrollment rate in 1960, average from 1970 to 1985 of the ratio of real private investment to real GDP, and the number of revolutions and coups. Although these are not all of Barro's variables, they are the most important ones, and include measures of general investment in human capital (primary education), in physical capital (private investment), and of government consumption.

We add to Barro's list the ratio of college enrollments in law to total college enrollments in 1970, and the same ratio for engineering. The reason that we choose total enrollments rather than population or population of a given age as a denominator is that we are interested in the allocation of the most able people between fields. Fractions of college enrollment in law and engineering in fact measure the incentives to be in these fields as opposed to being in college more generally. Looking at the ratios to population would tell us less about the allocation of the most able people and more about incentives to go to college. The intersection 
of the sample of countries for which data on college enrollments by field are available for 1970 with Barro's 98 country sample for which data on investment and government consumption are available yields 91 observations.

We run the regressions first for all 91 countries in the sample, and then for the 55 countries that have more than 10,000 college students. The idea of looking at countries with more than 10,000 students is to reduce the problem of college attendance abroad. We found this approach preferable to running populationweighted regressions since some large population countries have a significant commitment to education abroad. In addition, the subsample with large college enrollments gets rid of some smaller countries which probably have less reliable data, and might be preferred for this reason as well. Table II presents the summary statistics for the engineering and law variables in the total and the restricted sample.

Table III presents the basic results of the regression of 1970 to 1985 growth rate on law and engineering enrollments, controlling only for the 1960 GDP. In the regression for all countries, we find a positive and significant effect of engineers on growth, and a negative and basically insignificant $(t=1.2)$ effect of lawyers on growth. The signs of the coefficients are consistent with the theory that rent seeking reduces growth while entrepreneurship and innovation raise it. If an extra 10 percent of enrollment was in engineering, which corresponds roughly to doubling average engineering enrollments, the growth rate would rise 0.5 percent per year. If an extra 10 percent were in law, which also roughly corresponds to doubling enrollments, growth would fall 0.3 percent per year. If we look at countries with large student populations, the effect of engineers more than doubles and becomes more significant. The negative effect of lawyers also doubles, but remains insignificant. The R-squared 
of the second regression is a lot higher as well.

Of course, we cannot interpret these relationships as structural, since law and engineering enrollments might be correlated with other sources of growth.

Accordingly, we next consider the Barro regression augmented by our law and engineering variables, and then decompose the reduced form effects on law and engineering on growth into direct effects and indirect effects operating through correlation with other variables.

Table IV presents the results of the augmented Barro regression for the whole and the large college population samples. In both regressions investment in physical and in human capital increase growth, while government consumption and revolutions reduce growth. There is also some evidence of convergence as in Barro, although it is not clear that it makes sense to define convergence holding investment constant. The direct effects of lawyers and engineers are very insignificant in the whole sample, with the sign on engineers switching to negative. In contrast, the direct effect of engineering in the reduced sample is still positive and almost significant, although it falls to under half of the total effect in Table III. More surprisingiy, the direct effect of lawyers is negative and significant in the reduced sample, and its absolute value is higher than in the whole sample. Based on this sample, Table IV confirms the direct negative relationship between rent seeking and growth, and the direct positive relationship between entrepreneurship and growth.

The positive direct effect of engineers, and the negative direct effect of lawyers, are consistent with our theory, which says that the rate of technological progress is determined by the allocation of talent. If engineering is an attractive major, the quality of talent in engineering is higher, therefore entrepreneurs are of higher 
quality, the rate of technological progress is greater, and the growth rate of GDP per capita is higher. This argument of course assumes a positive correlation between the fraction of college majors in engineering and the rate of technological progress that they will generate and does not deal with the abilities of engineers. Similarly, if law is an attractive major, the quality of rent seekers is higher, and hence, indirectly, the quality of entrepreneurs is lower and technological progress and income growth are smaller. Of course, there may be other mechanisms that explain these direct effects, and our theory also predicts that there may be indirect effects of the allocation of talent on growth. For example, less rent seeking and more technological progress are likely to raise physical investment.

To decompose the total effect of lawyers and engineers on growth from Table III into the direct and indirect effects, Table $V$ presents the estimates from auxiliary regressions of Table IV independent variables (investment, primary education, government consumption, and revolutions) on lawyers and engineers. In all these regressions, we control for 1960 real GDP. High engineering enrollments predict high investment in pure and physical capital, low government consumption and low revolutions and coups. This suggests that some of the effect of engineers on growth comes from the fact that countries with many engineering majors also do many other things that are good for growth, such as educate the young and accumulate capital. They also avoid things that are bad for growth, such as government consumption and revolutions. Our engineering variable might be a proxy for good incentives and the efficiency of allocation on a variety of margins.

In contrast to the finding for engineers, the correlations between Table IV independent variables and law enrollments are weak and insignificant. To our 
surprise, lawyers do not have a significant negative effect on investment, which they would if rent seekers specialized in redistribution of physical capital. The results suggest that most of the effect of lawyers on growth is direct.

Table VI decomposes the total effect into the direct and the indirect effects. For engineers, the direct effect on growth is trivial for the whole sample, but about half of the total for the reduced sample. As we mentioned, this direct effect is consistent with the view that allocating good people to entrepreneurial activities is good for growth. In both samples, the indirect effects are large because engineering enrollments are strongly positively correlated with investment in physical and human capital, which are positively correlated with growth, and negatively correlated with government consumption, which is negatively correlated with growth. This result suggests that in countries that invest and have a good labor force attract their able people into engineering as well, and that as a result of this allocation of resources they grow. They do all the right things at the same time. They also avoid high government consumption, which discourages engineering majors, as well as reduces growth. Avoiding revolutions does not discourage engineering concentrators, and so there is no indirect effect there. Our results suggest, not surprisingly, that people choose the engineering major when other conditions in the economy make investment in industry-related human capital attractive.

The indirect effects of law enrollments on growth are all trivial. By far the main effect is direct, which in the reduced sample is even larger in magnitude than the total effect. This evidence from the reduced sample might mean that the most important effect of lawyers on growth is the opportunity cost of not having talented people as innovators. The small indirect effect suggests that lawyers reduce growth creating 
activities but not through reducing the incentives to invest.

In summary, the sample with large college enrollments reveals a large direct and large indirect positive effect of engineers on growth, and a large direct negative effect of lawyers on growth. One, but not the only one, interpretation of these findings is that the allocation of talent is important for growth. The allocation of talent into engineering seems to occur in countries that also invest in human and physical capital, suggesting that some countries just do things right.

\section{Conclusion}

Among the many explanations of the recent U.S. productivity growth slowdown, two deal with human capital. The first is that the quality of the U. S. human capital stock is not growing as fast as it used to, or perhaps is even deteriorating. The poor quality of schools, the declining test scores, and even the declining relative wages of high school graduates [Murphy and Welch, 1988] suggest that this might be a problem. The second explanation is that human capital is allocated improperly for growth, and in particular the most able young people become rent seekers rather than producers. The fact that many of the most talented young people become lawyers and security traders is cited as evidence for this explanation.

In this paper, we have presented some theoretical reasons why the second concern might in fact be important, and some empirical evidence that suggests that this concern might be real. Lawyers are indeed bad, and engineers good, for growth. This suggests that private incentives governing the allocation of talent across occupations might not coincide with social incentives. Some professions are socially more useful than others, even if they are not as well compensated. The findings on 
engineers also suggest that countries that have many engineering majors also invest in human and physical capital. We do not know what is the exogenous cause of these relationships. However, it is quite possible that policies that raise investment or improve the quality of human capital will indirectly make engineering a more attractive career, and in this way increase growth. 


\section{REFERENCES}

Arrow, Kenneth J., "The Economic Implications of Learning by Doing," Review of Economic Studies, 29 (1962), 155-173.

Ashton, T. S., The Industrial Revolution: 1760-1830 (London: Oxford University Press, 1948).

Baumol, William J., "Entrepreneurship: Productive, Unproductive, and Destructive," Journal of Political Economy 98 (1990), forthcoming.

Barro, Robert J., "Economic Growth in a Cross-Section of Countries," this Journal, CVI (1991), this issue.

De Soto, Hernando, The Other Path (New York: Harper and Row, 1989).

Krueger, Anne, "The Political Economy of the Rent-Seeking Society," American Economic Review, 64 (1974), 291-303.

Kuhn, Peter, "Unions in a General Equilibrium Model of Firm Formation," Joumal of Labor Economics, 6 (1988), 62-82.

Landes, David, The Unbound Prometheus (New York: Cambridge University Press, 1969).

Little. Ian M. D., Dipak Mazumdar, and John M. Page Jr., Small Manufacturing Enterprizes: A Comparative Analysis of India and Other Economies (New York: Oxford University Press for the World Bank, 1987).

Lucas, Robert E. Jr., "On the Size Distribution of Business Firms," Rand Journal of Economics, 9 (1978), 508-523.

Magee, Stephen P., William A. Brock, and Leslie Young, Black Hole Tariffs and the Endogenous Policy Theory (Cambridge: Cambridge University Press, 1989). 
Murphy, Kevin M. and Finis Welch, "The Structure of Wages," Mimeo (1988).

North, Douglass C. and Thomas, Robert Paul, The Rise of the Western World: A New Economic History (Cambridge: Cambridge University Press, 1973).

Olson, Mancur, The Rise and Decline of Nations (New Haven: Yale University Press, 1982).

Porter, Michael E., The Competitive Advantage of Nations (New York: Free Press, 1990).

Rosen, Sherwin, "The Economics of Superstars," American Economic Review, 71 (1981), 845-858.

Summers, Robert and A. Heston, "A New Set of International Comparisons for Real Product and Price Levels: Estimates for 130 Countries," The Review of Income and Wealth, 34 (March, 1988), 1-25.

Tullock, Gordon, "The Welfare Cost of Tariffs, Monopoly and Theft," Western Economic Journal, 5 (1967), 224-232. 
O'Hara, Maureen (1981), "Property Rights and the Financial Firm, "Journal of Law and Economtes, 24, 317-332.

Partch, Meghan (1987), "The Creation of a Class of Limited Voting Common Stock and Shareholder Wealth," Journal of Financtal Economics, fortincoming.

SEC (1986), "Self-Regulatory Organizations; Proposed Rule Change; New York Stock Exchange, Inc.," Eederal Reglscer, 51, 222, November 18, 41715 41718 .

Shlelfer, Andrel and Robert $W$. Vishny (1986), "Greenmall, White Knights, and Shareholder's Interest," The Rand Journal of Economics, 17, 3, Autumn, 293-309.

Shlelfer, Andrel and Robert W. Vishny (1986), "Large Shareholders and Corporate Control," Joumal of Political Economy, 24, 3, June, 461-488. 
Table I

Factors Favoring Rent Seeking and Entrepreneurship

\section{Factors making \\ rent seeking \\ an attractive choice}

Market size

Firm size

Contracts
Large resources go to

"official" rent-seeking

sectors, such as the

government, army, or religion.

Poorly defined property rights

make wealth accessible to

"unofficial" rent seekers.

Large wealth which is up for grabs, especially relative to smaller goods markets.

Substantial authority and discretion of rent seekers (such as government officials, army, etc.) enable them to collect large sums unhindered by law or custom.

Ability to keep a large chunk of collected rents. In firms, observability of output which yields appropriate rewards.

\section{Factors making entrepreneurship an attractive choice}

Large markets for goods. Good communications and transportation that facilitate trade.

Easy entry and expansion, few diminishing returns in operations, access to capital markets.

Clear property rights, patent protection.

No expropriatility of rents by rent seekers. Ability to start firms to collect quasi rents on talent. 
Table II

Summary Statistics for Engineering and Law Major as Percentage of College Students

\section{Full sample}

Engineering

10.39

9.08

3.83

14.31

75th percentile $\underline{\text { Law }}$

8.89

5.52

2.65

11.20

15.92

7.26
Countries with 10,000 or more students

Engineering

Law

12.03

7.25

5.61

3.10

0.05 
Table III

Regressions of Growth of Real GDP Per Capita between 1970 and 1985 on Proportions of Majors in Engineering and Law

All countries $\quad \geq 10.000$ students

Model

Constant

Engineering

Law

GDP 1960

$\mathbf{N}$

R-square
(1)

0.013

$(0.005)$

0.054

(0.027)

$-0.031$

$(0.025)$

0.000

$(0.001)$

91

0.09
55

0.23

(2)

0.015

(0.004)

0.125

(0.037)

$-0.065$

$(0.049)$

$-0.002$

$(0.001)$ 
Table IV

Determinants of Growth Rate of Real GDP Per Capita between 1970 and 1985

Model

(1)

(2)

Constant

0.018

0.020

$(0.010)$

$(0.011)$

Investment

0.086

(0.032)

0.085

$(0.039)$

Primary school

0.022

0.012

enrollment

$(0.009)$

(0.011)

Government

$-0.145$

$-0.064$

consumption

$(0.040)$

(0.053)

Revolutions and

$-0.028$

$-0.035$

coups

$(0.009)$

$(0.009)$

GDP 1960

$-0.007$

$-0.006$

$(0.001)$

$(0.001)$

Engineering

$-0.010$

0.054

$(0.023)$

(0.034)

Law

$-0.024$

$-0.078$

$(0.020)$

(0.040)

$\mathbf{N}$

91

55

R-square

0.47

0.56

Sample

All

$\geq 10,000$ Students 
Table V

Regressions of Table II Independent Variables on Proportions of Majors in Engineering and Law

\begin{tabular}{lcc} 
A. Estimated auriliary regressions for engineering & \\
\multicolumn{1}{c}{ Mode] } & $(1)$ & $(2)$ \\
Investment & 0.243 & 0.432 \\
& $(0.081)$ & $(0.119)$ \\
Primary & 0.904 & 1.02 \\
schooling & $(0.271)$ & $(0.408)$ \\
Government & -0.142 & -0.181 \\
consumption & $(0.056)$ & $(0.078)$ \\
Revolutions and & -0.090 & -0.300 \\
coups & $(0.265)$ & $(0.445)$ \\
N & 91 & 55 \\
Sample & All & $\geq 10,000$ Students
\end{tabular}

B. Estimated auxiliary regressions for law

Model

(1)

(2)

Investment

$-0.093$

0.055

$(0.076)$

Primary

$-0.093$

0.576

schooling

(0.254)

(0.548)

Government

0.006

$-0.089$

consumption

(0.053)

(0.105)

Revolutions and

$-0.121$

(0.248)

0.141

coups

91

(0.597)

$\mathbf{N}$

All

55

Sample

$\geq 10,000$ Students 
Table VI

Decomposition of the Effect of Engineering and Law Majors on Growth into Direct and Indirect Effects

\section{A. Estimated effects for engineering}

\begin{tabular}{lcc}
\multicolumn{1}{c}{ Model } & (1) & $(2)$ \\
Investment & 0.021 & 0.037 \\
$\begin{array}{l}\text { Primary } \\
\text { schooling }\end{array}$ & 0.020 & 0.012 \\
$\begin{array}{l}\text { Government } \\
\text { consumption }\end{array}$ & 0.021 & 0.012 \\
$\begin{array}{l}\text { Revolutions and } \\
\text { coups }\end{array}$ & 0.002 & 0.003 \\
Direct & 0.010 & 0.054 \\
Total & 0.054 & 0.125
\end{tabular}

B. Estimated effects for law

Model (1) (2)

$\begin{array}{lll}\text { Investment } & -0.008 & 0.005\end{array}$

$\begin{array}{lll}\text { Primary } & -0.002 & 0.007\end{array}$

schooling

Government

$\begin{array}{ll}-0.001 & 0.006\end{array}$

consumption

$\begin{array}{lll}\text { Revolutions and } & 0.004 & -0.005\end{array}$

coups

Direct

$-0.024-0.078$

Total

$-0.031$

$-0.065$ 